\title{
CHARACTERIZATION OF MEDIEVAL GLASS FROM CIZRE CASTLE EXCAVATION BY SEM-EDS AND P-EDXRF ANALYSES
}

\section{CiZRE KALESI KAZIII'NDAN ELE GEÇEN ORTAÇAĞ CAM ÖRNEKLERININ SEM-EDS VE P-EDXRF ANALizLERi iLE KARAKTERIZASYONU}

\author{
Makale Bilgisi Article Info \\ Başvuru: 11 Nisan 2020 Received: April 11, 2020 \\ Hakem Değerlendirmesi: 18 Mayıs 2020 Peer Review: May 18, 2020 \\ Kabul: 15 Haziran 2020 Accepted: June 15, 2020
}

DOI : $10.22520 /$ tubaar.2020.26.008

\section{Mahmut AYDIN * - Akarcan GÜNGÖR **}

Anahtar Kelimeler: Antik Camlar, Cam Analizleri, Cizre Kaleiçi Kazısı Camları, Camlarda XRF Analizi, Camlarda SEM-EDS Analizi

Keywords: Ancient Glasses, Glass Analyses, Cizre Castle, P-XRF Analysis of Glasses, SEM-EDS Analysis of Glasses

ÖZET

Şırnak İli Cizre İlçesinde yer alan Cizre Kalesi Kazıları'nda 2013-2017 yılları arasında ele gecen cam örnekler arkeometrik yönden incelenmiştir. Cam örnekler öncelikle form özelliklerini yansıtacak şekilde görsel olarak tanımlanmış, fotoğraflanarak belgelenmiş ve kodlanmıştır. Cam örneklerinin yapım teknikleri hem görsel hem de taramalı mikroskop altında habbe şekillerine göre belirlenmeye çalışılmıştır. Örneklerin element ve mineralojik içerikleri taşınabilir Enerji dağılımlı X-ışınları floresans spektroskopi (P-EDXRF) ve Taramalı Elektron MikroskobuEnerji Dağılımlı Spektroskopi (SEM-EDS) yöntemleri ile analiz edilmiştir. Analiz sonuçları cam örneklerin 7 tanesi soda camı iken diğer 7 si potasyum kireç camı olduğu anlaşılmıştır. Örneklerin yüksek Si içerikleri, camların hem mekanik direnç ve dayanıklılığın, hem de ergime sıcaklığının yüksek oluşuna işaret etmektedir. Cam örneklerin üretiminde bir örnek hariç bitki külü (K ve/veya $\mathrm{Mg}$ ) kullanılmamıştır. Cam örneklerin $\mathrm{Al}$ içeriklerindeki farklılık örneklerin hammadde adresini ayrı kaynaklara dayandırmaktadır. Sr ve Zr'nin tespit edilmemiş veya düşük oranlarda olması karasal hammadde kullanılmış olduğunu göstermektedir. Camlarda renk veren elementler; Fe, Co, Mn ve Cu'dur.

\footnotetext{
* Doç. Dr., Department of Archaeology, Faculty of Science and Letters, Batman University, Batman, Turkey e-posta: aydinm135@gmail.com ORCID: 0000-0003-4707-5387

** Öğr. Gör., Department of Sason Vocational School, Artifact Conservation Programme, Batman University, Batman, Turkey e-posta: akarcangungor@gmail.com ORCID: 0000-0001-5372-9733
} 


\section{ABSTRACT}

The ancient glass artifacts uncovered in Cizre Castle excavations between 2013-2017 in Şırnak province were analysed archaeometrically, ensuring all samples were recorded and catalogued appropriately. The production techniques of the samples were determined in terms of sample pore shapes via scan electron microscope analysis (SEM). The elemental and mineralogical structure of the glass samples were analysed via portable energy dispersive X-ray fluorescence spectroscopy (P-EDXRF) and Scanning Electron Microscopy coupled with X-Ray Energy Dispersive (SEM-EDS). Complementary analysis showed that seven pieces of glasses are soda/lime glass and other seven are potash - lime glass. Also, the high $\mathrm{SiO} 2$ content of the samples not only illustrated the high mechanical strength and durability, but also proved that they have high melting temperatures. The low rate of $\mathrm{K}$ and/or $\mathrm{Mg}$ showed that plant ash was not present in the glass samples and the different rates of Al content in the samples addressed the different sources of the raw materials. The absence or low values of $\mathrm{Zr}$ and $\mathrm{Sr}$ in the material analysis emphasized that materials obtained for production of glass were terrestrial. Finally, detection of $\mathrm{Fe}, \mathrm{Mn}, \mathrm{Co}$ and $\mathrm{Cu}$ elements were discovered to be used as colorants for the glasses. 


\section{INTRODUCTION}

The Cizre district of Şirnak province is located in the south, near the intersection of the Cudi and Gabar mountain ranges in the Southeastern Anatolia Region and southern bank of the Tigris River. Cizre, located in Upper Mesopotamia, was established as the junction of strategic and equally important commercial and military routes (Fig. 1).
Archaeological excavations were carried out in Cizre Castle between 2013 and 2017 under the presidency of Mardin Museum Directorate, with the permission of the Ministry of Culture and Tourism, and thanks to the financial supports of the Ministry of Development and the District Governorship of Cizre. All of these archaeological excavations in Cizre Castle were carried out under the scientific consultancy of Prof. Dr. Gülriz Kozbe.

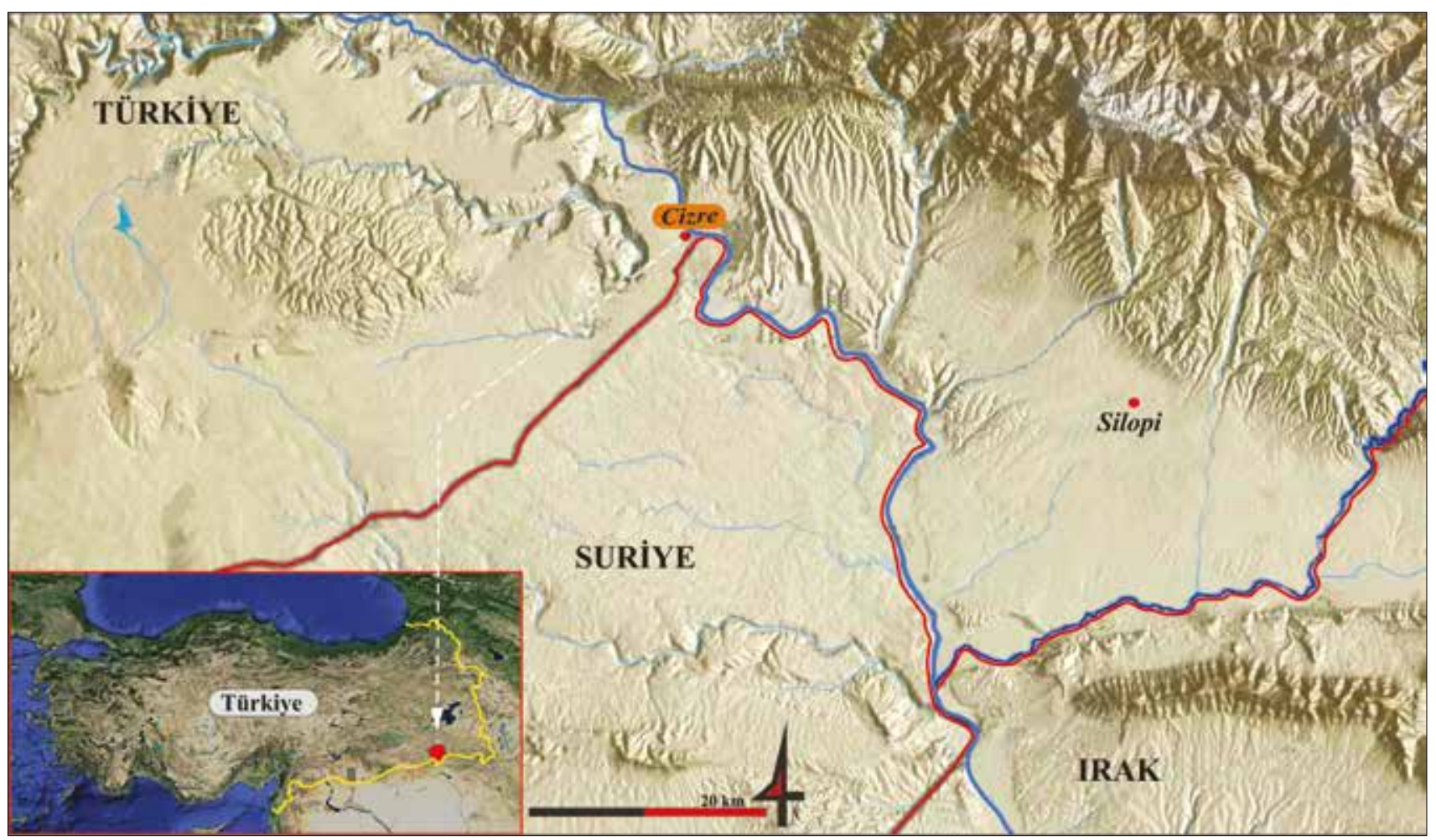

Figure 1: Location of Cizre Castle / Cizre Kalesi'nin Konumu

Concluding the Islamic conquests in $639 \mathrm{AD}$, the region was renamed as "Al-Jazeera", which means "island" in Arabic, the Tigris River curls up in this area forming a peninsula. It was also named as "Cezire-i İbn-i Ömer" by linking to the city ruler Khalif Omar.

Cizre Castle, up until recently, was considered as a historically significant area of the city, and scientific explorations were restricted in the area due to the security measures taken because of the fact that the area is a military zone for the past 135 years.

In 2010, the area was used by the Border Battalion Command and soon after it was evacuated by the army forces and this allowed the restoration of the walls in 2013, with a project titled as "Resurrecting the City of Noah" organized by the Cizre District Governorate.[1]

1 Kozbe/Gök 2018; 309-312.
The castle, which was established on a flat area of approximately 50 hectares in the centre of Cizre, consists of two parts, the inner and outer portion of the castle, as well as many other castles in Anatolia.

All archaeological excavations in the castle were carried out in various sectors such as Sarayburnu, Lion Gate, Headquarters Building, Seyfiye Masjid and Madrasah, Cafeteria building, City wall front, and the Annexed part of the building. The most prominent discoveries were the glass artifacts in the Cizre Castle, each of which varies according to production techniques, form, decoration, and usage patterns.

\section{The Aim and Importance of the Study}

The aim of this study is to determine the raw materials, production techniques, element contents, and obtain 
scientific information about resources of raw material by using archaeometric techniques on selected amorphous samples obtained from different sectors in Cizre Castle.

These excavations unveiled the artifacts of both raw materials and construction techniques which revealed further the history, structural features, and production centers of Anatolian glass production, an area of expertise in which little is currently known. ${ }^{2}$ This is why it is necessary to understand the technology of glass production and the determination of raw material sources and identification of chemical content in terms of archaeometry.

During the 2015 excavation season, Cizre Castle Excavation Scientific Consultant Prof. Dr. Gülriz $\mathrm{KOZBE}^{3}$ sent glass samples to the faculty in the Department of Archaeology at Batman University. These results focused on 14 pieces (BTV 1, BTV2, BTV3, BRP, AFR, AFM, BSI, ASV, BDD, ABT, BRE, AMU, BMD, AEE) of unclassified glass samples each of which was given their own unique 3 letter coding system.

\section{SAMPLES AND ANALYTICAL METHODS Sampling}

Archaeometric studies were conducted on a total of 14 different glass samples (Fig. 2) uncovered in the Cizre District of Şırnak Province. Most of these glass samples were found in the annexed part of Cizre Castle. Within the samples there was a particular sample with a transparent colour (BDD) that was found in the inner castle, in an area called trench M6d. The M6 trench actually held a large number of finds with glassware such as tobacco pipes, oil lamp fragments, imported porcelain ceramic pieces, and glazed/unglazed ceramic pieces.

The bluish or light blue coloured glass fragment (BRE) was found in the Complex Structure with preserved architectural texture in D5 trench in the annexed part of the building. Samples of light blue, dark blue and green coloured glass from BTU code were found in the street structure $(\mathrm{C} 5 \mathrm{a}+\mathrm{c})$ in the south of the Complex and in the ruins of the destroyed building.

The glass piece (BMD), known to be a black-coloured bracelet fragment, was majorly located in the southeast portion of the Complex building. Unfortunately, this area had witnessed excessive destruction, causing the architectural texture of the samples to be deteriorated.

In the Bath Structure (H5b), one of the most striking sectors in the annexed part of the building area, there were findings of a greenish or light green coloured piece of glass (BSI). The blue coloured glass fragment (BRP), which is thought to belong to the plate form, was found in the eastern part of the annexed part of the building whose outer face was covered with basalt stones and inner part includes water channel systems and wells (G9a). The light green coloured glass fragments belonging to the ABT and AFM codes were found in an area $(E 3 c+E 4 c)$ in the west of the Complex building, with a mortared stone paved floor. In the east of the Complex building (E6c), a light-green amorphous glass fragment (AMU) was found and a green bracelet fragment (AEE) was found in the E7b trench in the southern, most severely damaged part of the water channel.

The dark purple coloured glass fragment (ASV) and the dark blue coloured glass fragment (AFR) were detected in $\mathrm{E} 8 \mathrm{c}+\mathrm{d}$ trench within the boundaries of the Cemetery Area in the annexed part of the building.

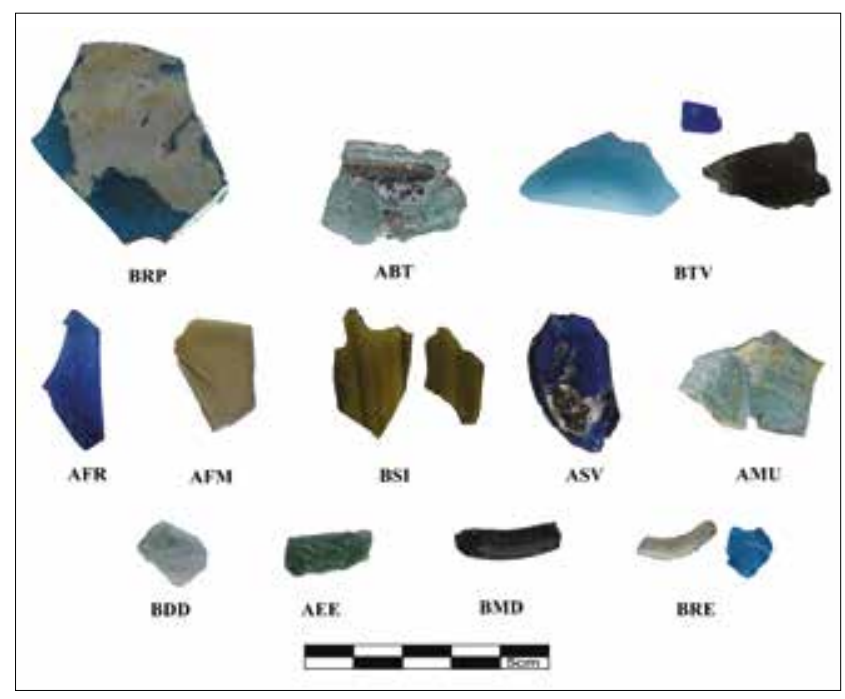

Figure 2: Glasses unearthed in Cizre Castle Excavation / Cizre Kalesi Kazısı 'ndan Ele Geçen Camların Fotoğrafları

\section{Methods}

Within the scope of this study, 14 samples were evaluated visually, photographed, documented, and coded. Pulp colours of the samples were documented by chromametric analysis (Table 1) and colour code studies were performed on 12 out of 14 glass samples.

Sample colours were identified with chromametric analysis performed by a portable colorimeter using the standard CEI L * a $* b *$ (Commission Internationale de L'Eclairage) colour system. ${ }^{4}$ The value (L) between 0 and 100 indicates the lightness / darkness (white: 100 / black: 0), the value of " $+a$ " (between 0 and +60 )

\footnotetext{
${ }^{4}$ Ohno 2007: 101-132.
} 

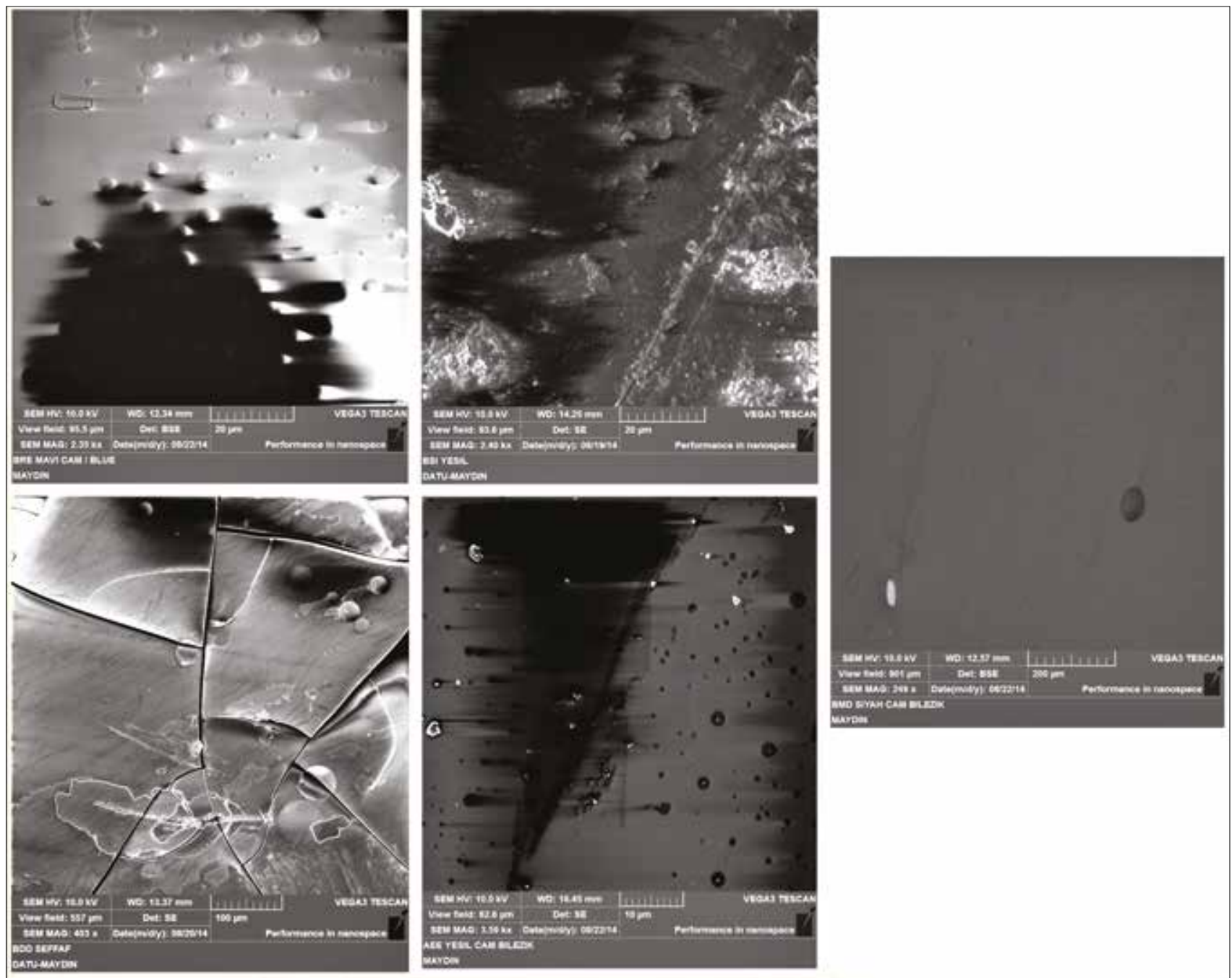

Figure 3: Scanning electron microscopy images of the selected samples / Seçilen Örneklerin Taramalı Elektron Mikroskobu (SEM) Görüntüleri

indicates the intensity of red in the colour, "-a" indicates the green intensity of the colour, (between 0 and +60 ). Finally, the intensity of the color yellow and the value of (-b) (between 0 and -60) indicates the intensity of the blue colour.

In this study, Scanning electron microscopy coupled with energy dispersive X-ray spectrometry (SEM-EDS) was used to determine the chemical composition of 14 glass pieces and helped visualize the material structure. Scanning electron microscope (TESCAN Easy SEM) compatible with Bruker X-Flash 410-M detector (Software: Esprit 1.9) was used in the study ${ }^{5}$. SEM-EDS was widely used to determine chemical composition of ancient glasses and to understand material structure and production technique. $^{6}$

\footnotetext{
5 We would like to thank the Turkish Culture Foundation and its staff Emine TORGAN GÜZEL and Prof. Dr. Recep KARADAĞ for their analysis of the SEM-EDS.

6 Li/Liu/Su/Zhao/Fu/Dong 2012: 133-140;Kursula 2000: 111 118.
}

The other technique used to determine chemical composition of studied 14 glass pieces was portable X-Ray Florescence Spectroscopy (P-EDXRF). XRF involves emission of characteristic X-rays from a material that has been excited by bombardment with high-energy X-rays. This phenomenon is used in archaeological research for elemental (chemical) analysis in the investigation of archaeological materials such as metals, glass, ceramics, and sediments. It provides quantitative chemical data regarding major elements and several trace elements in the composition of glasses.?

In this study, Olympus Delta Premium Portable X-Ray Fluorescence Spectrometer (P-EDXRF), which is widely used for the analyses of the archaeological materials (glass coins, paintings etc.), was used. ${ }^{8}$

\footnotetext{
Mantler/ Schreiner 2000: 3-17; Speakman/Little/Creel/Miller/ Iñañez 2011: 3483-3496.
}

8 Spencer/Murdoch/Buckman 2018: 1018-1035; Cavallo 2011: 161-174. 
Table 1: Colour Codes of Glasses / Cam Örneklerin Renk Kodlart

\begin{tabular}{|l|c|c|c|c|}
\hline & \multicolumn{3}{|c|}{ Colours Code } & \multirow{2}{*}{ Observed Colours } \\
\hline Glasses codes & L & $\mathbf{a}$ & b & Light blue \\
\hline BTV1 & 70.95 & -13.88 & -16.34 & Green \\
\hline BTV2 & 33.28 & -1.42 & 7.91 & Blue \\
\hline BRP & 48.87 & -29.51 & -13.19 & Blue \\
\hline AFR & 42.51 & 3.89 & -30.04 & Light Green \\
\hline BSI & 75.93 & 1.31 & 21.16 & Green \\
\hline ABT & 41.11 & 2.16 & 22.46 & Light Green \\
\hline ASV & 53.79 & -6.65 & -1.62 & Dark purple \\
\hline BDD & 27.97 & 8.12 & -21.15 & Transparent/ Yellowish \\
\hline BRE & 74.42 & -4.24 & 10.41 & Blue \\
\hline AMU & 51.66 & -24.24 & -19.47 & Light Green \\
\hline AEE & 63.83 & -6.2 & 2.41 & Green \\
\hline & 49.99 & -3.13 & 5.58 & $\mathbf{0}$ \\
\hline
\end{tabular}

Furthermore, qualitative and quantitative analyses of all the following elements in geological material mode were performed for 140 seconds in each sample.

Using two different beams in Geochem Mode (10 \& 40 $\mathrm{KV}$ ) allowed the following elements to be detected: V, $\mathrm{Cr}, \mathrm{Fe}, \mathrm{Co}, \mathrm{Ni}, \mathrm{Cu}, \mathrm{Zn}, \mathrm{Pt}, \mathrm{W}, \mathrm{Hg}, \mathrm{As}, \mathrm{Se}, \mathrm{Au}, \mathrm{Br}, \mathrm{Pb}$, $\mathrm{Bi}, \mathrm{Rb}, \mathrm{U}, \mathrm{Sr}, \mathrm{Y}, \mathrm{Zr}$, Th, Nb, Mo, LE, Ag, Cd, Sn, Sb, $\mathrm{Mg}, \mathrm{Al}, \mathrm{Si}, \mathrm{P}, \mathrm{S}, \mathrm{K}, \mathrm{Ca}$, Ti and Mn. Unfortunately, one disadvantage of using P-EDXRF in glass analyses is that elements with atomic number 11 and smaller (such as "Na') cannot be detected.

The reason of using P-EDXRF beside SEM-EDS is to compare the results of SEM-EDS with P-EDXRF. $\mathrm{P}-\mathrm{EDXRF}$ analysis results are not reliable as much as SEM-EDS because SEM-EDS cannot analyse $\mathrm{Na}$ and $\mathrm{C}$ which are important elements in the production of glass. However P-EDXRF can analyse glass colorant elements such as $\mathrm{Co}, \mathrm{Mn}, \mathrm{Fe}$ and $\mathrm{Cu}$.

\section{EVALUATION OF ANALYSIS RESULTS}

When SEM-EDS results are compared with P-EDXRF; $\mathrm{Ca}$, Si and $\mathrm{K}$ values of P-EDXRF are higher than SEMEDS. $\mathrm{Na}$ and $\mathrm{C}$ could not be analysed by P-EDXRF so these elements are higher than SEM-EDS analysis results.
$\mathrm{LE} / \mathrm{O}$ value of P-EDXRF is less than SEM-EDS results.

The main components of soda-lime glasses are $\mathrm{SiO} 2$, $\mathrm{Na} 2 \mathrm{O}$ and $\mathrm{CaO}$. In terms of quantity, such glasses consist of $73 \% \mathrm{SiO} 2,12 \% \mathrm{Na} 2 \mathrm{O}, 10 \% \mathrm{CaO}, 4 \% \mathrm{MgO}$ and $1 \% \mathrm{Al} 2 \mathrm{O} 3$. In glasses, alkali $\mathrm{Na} 2 \mathrm{O}$ oxides are used as melting point reducer and $\mathrm{CaO}$ is used as strengthener in glasses. ${ }^{9}$

It is important to know the strontium ( $\mathrm{Sr}$ ) and zirconium ( $\mathrm{Zr})$ contents of the samples for raw material origin. $\mathrm{Sr}$ is geochemically similar to $\mathrm{Ca}$ and contains limecontaining substances (such as seashells, limestone and plant ash). In terrestrial sands containing limestone, $\mathrm{Sr}$ is generally less than $150 \mathrm{ppm}$. Thus, $\mathrm{Sr}$ values higher than 400 ppm usually suggest that the sand used in glass production is mainly from marine environments. ${ }^{10}$ One test that can be conducted to prove this statement is to check $\mathrm{Zr}$ values. If terrestrial sand is used in production, $\mathrm{Zr}$ value is expected to be bigger than 160 ppm. ${ }^{11}$

\footnotetext{
9 Akyol/Canav/Kadıŏlu/Demirci 2011: 161-174; Akyol/Kadıŏlu/Canav/Özgümüş/Kaynak 2014: 6-10.

${ }^{10}$ Freestone/Leslie/Thirlwall/Gorin-Rosen 2003: 19-32.

${ }^{11}$ Akyol/Kadıŏlu 2015: 31-35.
} 


\section{Chemical Composition P-EDXRF and SEM-EDS}

When the results of SEM-EDS and P-EDXRF analysis examined (Table 2, Fig. 4-5), it was concluded that:

The sodium $(\mathrm{Na})$ value obtained from SEM-EDS analysis was examined, and it showed that 7 samples (BTV 3, BTV 2, BRP, ASV, BRE, DDD, AEE) ranged from $7.64 \%$ to $13.66 \%$, where on the half of the samples melt reducers were used and on the other half ( $\mathrm{Na}$ less than $2 \%$ ) was not.

$\mathrm{Na}$ cannot be analysed in P-EDXRF analysis therefore P-EDXRF cannot help to evaluate $\mathrm{Na}$ results.

Si value is important in glass production. According to P-EDXRF, Si average is $38.1 \%$ and SEM-EDS average is $25.2 \%$ (Table 2). The $\mathrm{Si}$ value of the glasses is high and has a negative correlation with $\mathrm{Na}$ (Fig. 4).

When the potassium $(\mathrm{K})$ values were examined, SEM-EDS and P-EDXRF results were high in the BTV 1 sample (SEM-EDS 3.41\%, P-EDXRF $12.02 \%$ ), which shows that plant ash was used in the production of this sample. On the contrary, an average of around $1 \% \mathrm{~K}$ was found in the other analysed samples, indicating that no plant ash was used in their production. ${ }^{12}$

According to SEM-EDS results of the analysed glass samples, $\mathrm{Sr}$ and $\mathrm{Zr}$ could not be determined. In terms of P-EDXRF results, Sr values were found to be around $400 \mathrm{ppm}$ but $\mathrm{Zr}$ values were $120 \mathrm{ppm}$ (Table 2). From these results, it can be inferred that terrestrial raw materials were used in the production of Cizre Castle excavation glasses. When the Sr analyses of Olba excavation glasses were examined, it was found that $\mathrm{Sr}$ was detected in $1.5 \%$ and marine raw materials were used. ${ }^{13}$

The calcium $(\mathrm{Ca})$ analysis average of SEM-EDS and P-EDXF results are $1.89 \%$ and $5.49 \%$ respectively. When the results of the samples were examined individually (Table 2), none of the samples had a $10 \%$ Ca content, revealing that the strength of the glass in Cizre Castle was inherently low compared to other samples.

\footnotetext{
${ }_{12}$ Freestone/Leslie/Thirlwall/Gorin-Rosen 2003: 19-32; Silvestri/ Molin/Salviulo 2005: 797-816; Silvestri/Molin/Salviulo 2006: 415-432; Silvestri 2008:1489-1501; Tite/Shortland/ Maniatis/ Kayoussanaki 2006: 1284-1292.

${ }^{13}$ Aydın/Akyol/Erten/Torgan 2015: 207-220.
}

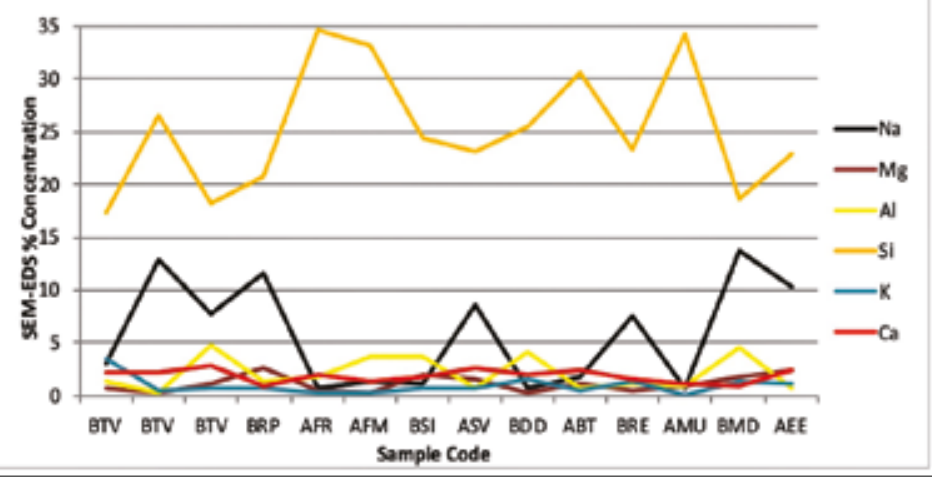

Figure 4: The variation of $\mathrm{Na}, \mathrm{Mg}, \mathrm{Al}, \mathrm{Si}, \mathrm{K}$ and $\mathrm{Ca}$ elements identified through SEM-EDS / SEM-EDS analiz sonuçlarına göre $\mathrm{Na}, \mathrm{Mg}, \mathrm{Al}, \mathrm{Si}, \mathrm{K}$ ve Ca elementlerinin dağılımı

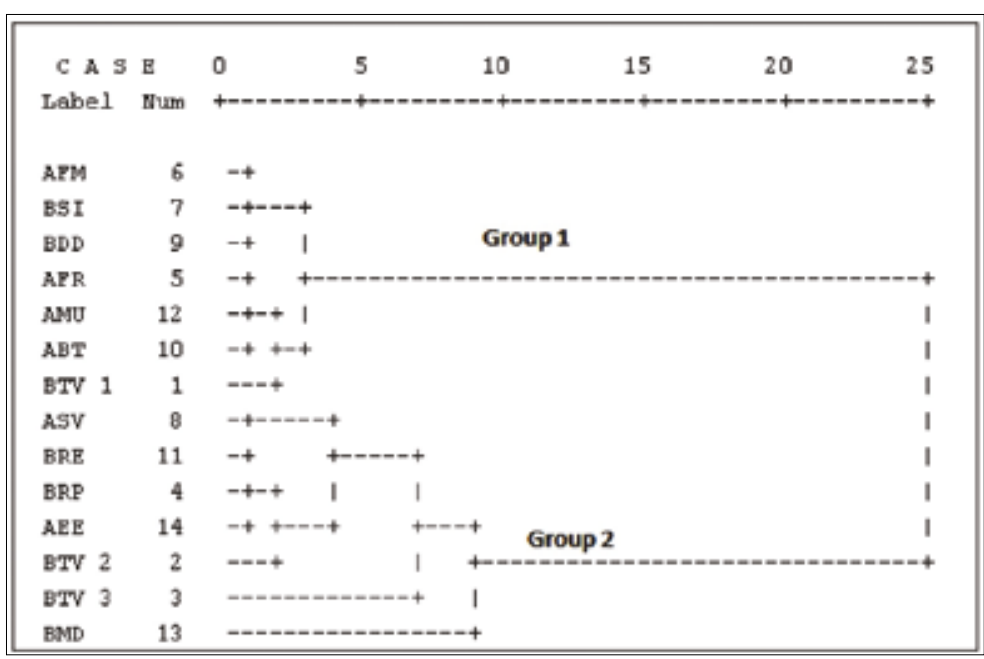

Figure 5: Hierarchical cluster analysis dendrogram showing the grouping of the samples considering the SEM-EDS (Na and $\mathrm{Al}$ ) results / SEM-EDS (Na ve Al) analiz sonuçlarına göre örneklerin hiyerarşik gruplama analizi

In regards to the values of $\mathrm{Al}$, which strengthens the usage of quartz, it can be discovered if the glasses are made from the same raw material, or if they are found to be consisted of two groups to overlap with each other close enough. The differences in the $\mathrm{Al}$ contents of the glass samples, SEM-EDS results range between $4.77 \%$ and $0.34 \%$, according to P-EDXRF results range between $6.06 \%$ and $0.22 \%$. The raw material addresses of the samples are based on separate sources.

AFM, BSI, BTV 3, BDD and BMD coded samples differ from the other samples with $\mathrm{Al}$ value around $4 \%$.

The clear dissimilarity in the amounts of such trace elements between the two groups suggests that the deposits would have been used in the production of the glasses in Cizre. This assumption was further validated using the SPSS statistical program in which identified $\mathrm{Na}$ and $\mathrm{Al}$ elements were included 


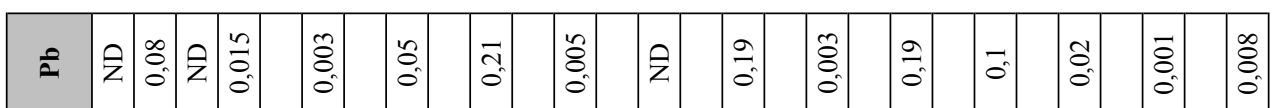

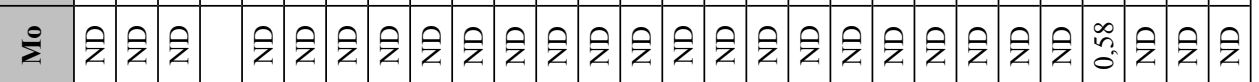

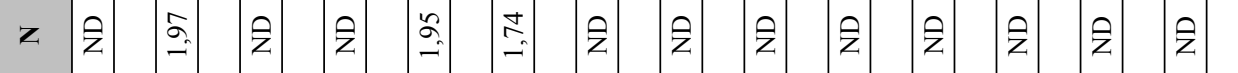

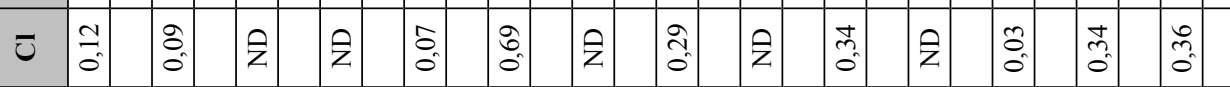

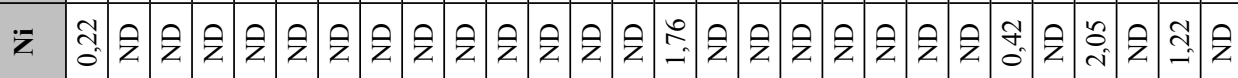

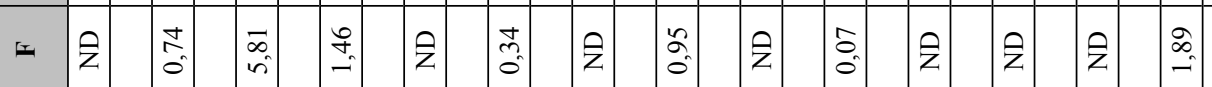

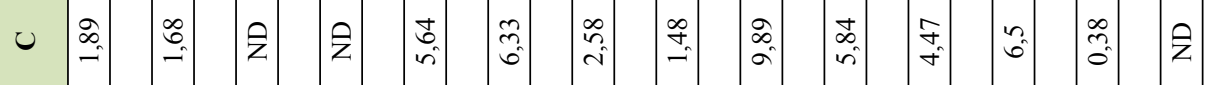

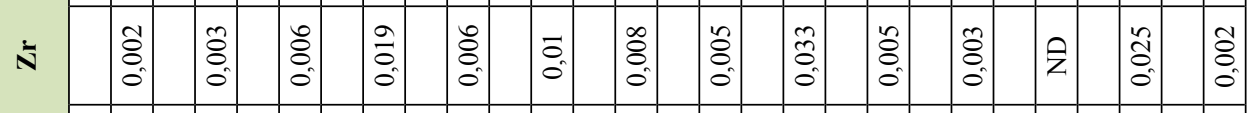

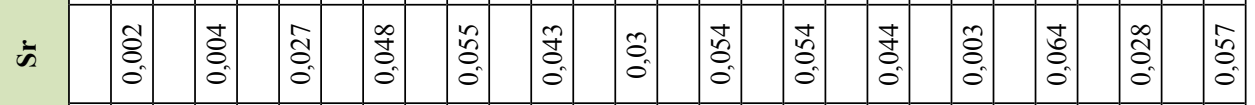

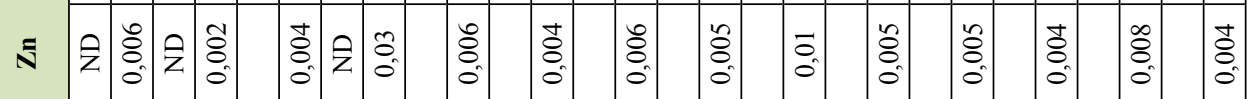

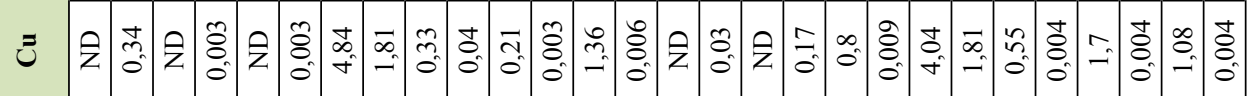

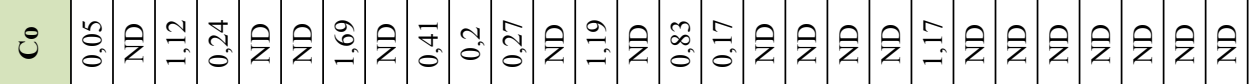

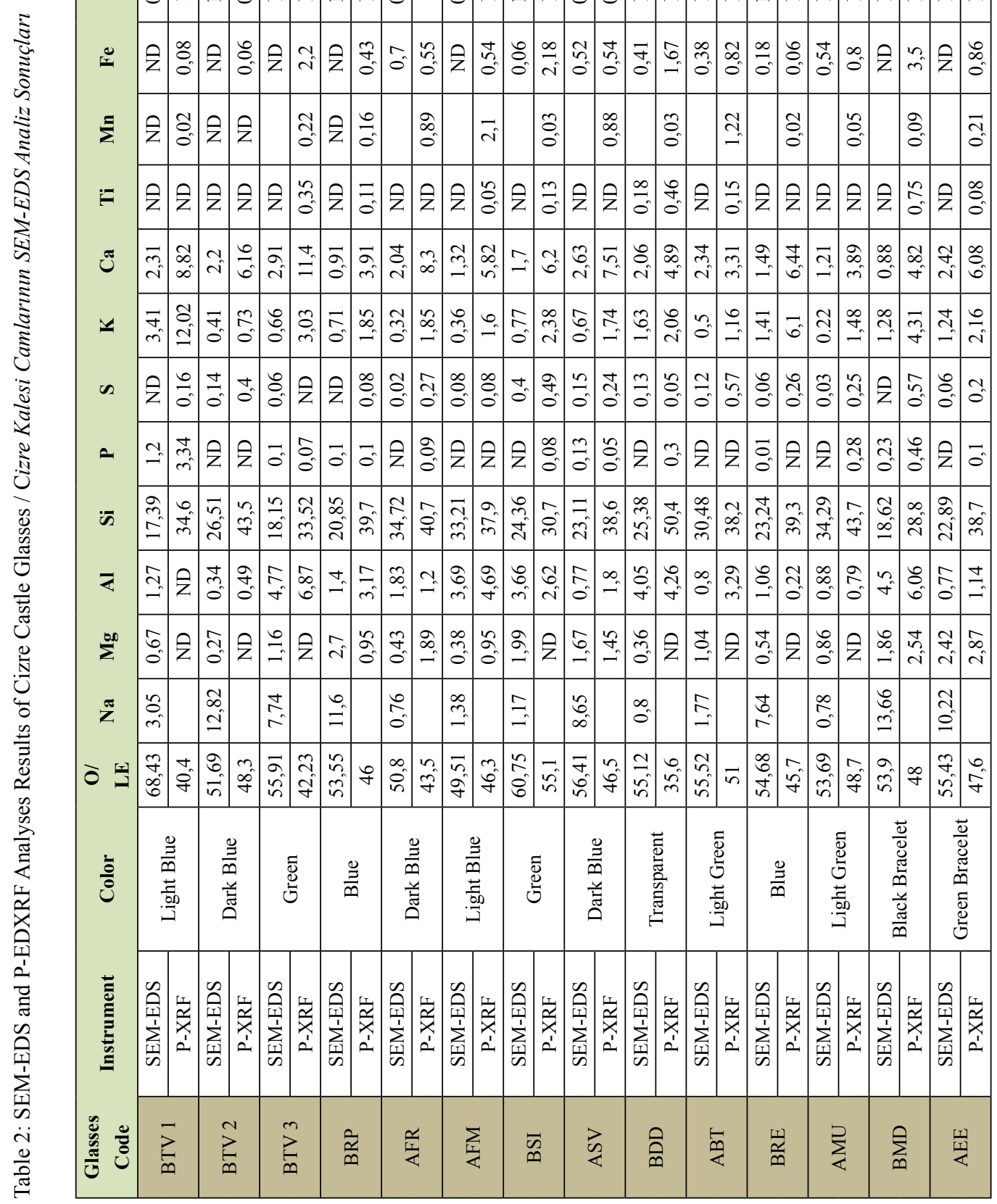




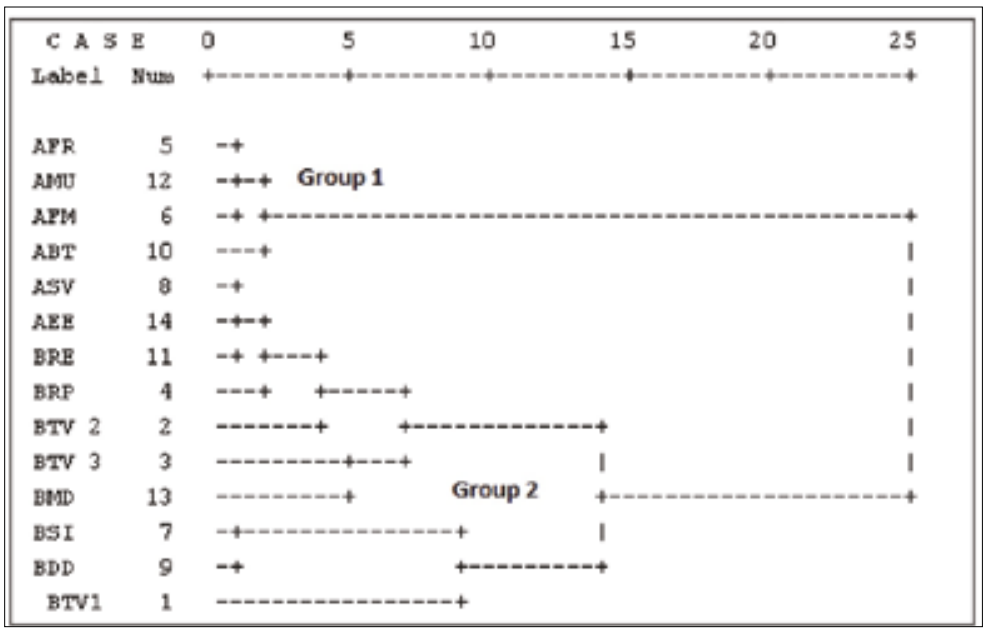

Figure 6: Hierarchical cluster analysis dendrogram showing the grouping of the samples considering the SEM-EDS ( $\mathrm{Na}, \mathrm{Mg}, \mathrm{Al}, \mathrm{Si}, \mathrm{K}$, and $\mathrm{Ca}$ ) results. / SEM-EDS (Na, Mg, Al, Si, K, and Ca) analiz sonuçlarına göre örneklerin hiyerarşik gruplama analizi

for the hierarchical clustering analysis (Fig. 5). The representative samples assisted in the differentiation of the groups (including high $\mathrm{Na}$ and different amount of $\mathrm{Al})$.

First group: AFM, BSI, BDD, AFR, AMU, ABT, BTV 1.

Second Group: ASV, BRE, BRP, AEE, BTV 3, BTV 2, BMD.

A second dendrogram was done to check and validate the first by taking $\mathrm{Na}, \mathrm{Mg}, \mathrm{Al}, \mathrm{Si}, \mathrm{K}$, and $\mathrm{Ca}$ in account (Fig. 6). The results from the second dendrogram were similar to the first and the samples were again differentiated into two groups (Fig. 6).

In glass, the main elements that usually affect colour are $\mathrm{Fe}, \mathrm{Mn}, \mathrm{Co}$ and $\mathrm{Cu}$. It was determined that in addition to $\mathrm{Cu}$, Co was used in BRE, BRP and BRE samples. It was found that Co was used as the blue donor in the other blue coloured glasses, BTV, AFR, ASV and BRE samples (Table 2).

According to the results of P-EDXRF analysis in light green glasses (Table 2), manganese $(\mathrm{Mn})$, which is generally used as colour brightener as decolorization agent, was used as colorant. Although BSI sample is green, cobalt was detected in it. The reason of this should be the recycled of materials. ${ }^{14}$

In the transparent / yellowish BDD coded glass sample $\mathrm{Mn}$ and $\mathrm{Fe}$ were thought to be used as colour regulator.

It was understood from the bubbles and their shapes taken by SEM that the glasses were produced by blowing techniques (Figure 3).

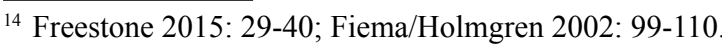

\section{CONCLUSION}

SEM-EDS and P-EDXRF analyses of the glass samples obtained from the Cizre Castle excavation provided information worth reporting about the contents and origins of these samples.

Samples were divided into two groups in terms of $\mathrm{Na}$ values.

Group 1 have a Na value between 3-10\% BTV 3, BTV 2, BRP, ASV, BRE, AEE, BDD, BMD,

Group 2 samples with a Na value of less than $2 \%$ consist of: AFM, BSI, BDD, AFR, ABT, AMU and BTV1. It may be assumed that Na used as a melting material was not very apparent in some samples while $\mathrm{Si}$ increases in these samples, indicating that mechanical resistance, durability, and melting temperature are high.

The value of $\mathrm{Al}$, which gives information about the origin of glass, showed that the glasses can be separated to at least two groups. The first group consists of: AFM, BSI, BTV 3, BDD and BMD; all of which had an Al value between 3.66-4.77\%. The second group had an $\mathrm{Al}$ value between 0.34 and $1.88 \%$. This group had results very similar to SPSS cluster analysis results.

When looking at the origin of the raw materials that make up the glass (based on $\mathrm{Sr}$ and $\mathrm{Zr}$ values), it was found that the glass uncovered in Cizre district of Şırnak province, which has no coastline remarks, used a terrestrial raw material.

Calcium (Ca), which has resistance-enhancing properties in the raw material of glasses, was low in all samples (around 2\%), causing the glasses to be produced with low resistance.

It was also found that Co was used as a colourant element in the glasses to elicit a blue colour in BTV1 and BTV2, AFR, ASV and BRE samples. In addition to $\mathrm{Co}, \mathrm{Cu}$ was also used in BRE and BRP samples to present a blue hue. $\mathrm{Mn}$ and $\mathrm{Fe}$ were the other colourants and brighteners used in the BDD sample, which has transparent, yellowish colours.

When the analysis results of Cizre glasses are evaluated with other analyzes glasses in Anatolia and other parts of ancient world, it is understood that even in medieval age Cizre glasses produced in the same way that Roman glasses were produced with the coloring elements, raw material and production technique. 


\section{REFERENCES}

AKYOL, A.A. / KADIOĞLU Y.K. 2015.

"Tekfur Sarayı Cam Buluntuları Arkeometrik Çalışmaları", TÜBA-KED 13,31-35.

AKYOL, A.A. / KADIOĞLU, Y.K. / CANAV Ö. Ü. / KAYNAK, S. 2014.

İstanbul Koca Ragıb Paşa Kütüphanesi Camları Arkeometrik Analizler, International Periodical For the Languages, Literature and History of Turkish, Cilt 9/10, 6-10.

AKYOL, A. A. / CANAV, Ö.Ü. / KADIOĞLU Y. K. / DEMIRCI, Ş. 2011.

"İstanbul Yeni Cami Hünkar Kasrı Camları Üzerinde Arkeometrik Çalışmalar”, II. ODTÜ Arkeometri Çalıştayı, Ankara,161-174.

AYDIN, M. / AKYOL, A. A. / ERTEN, E. / TORGAN E. 2015.

"Olba Kazısı Camları Arkeometrik Çalışmaları", Seleucia ad Calycadnum, V, 207-220.

BAKIRER, Ö. 1985.

"Cam Buluntuların Değerlendirilmesinde Arkeometrik Araştırmaların Önemi”, VII. Kazı Sonuçları, I. Arkeometri Toplantısı Bildiriler Kitabı, Ankara, 61-67.

CAVALLO, G. / CARDAS VERGANI, R. / GIANOLA, L. / MEREGALLI, A. 2011.

"Century Ad Painted Fragments from the San Giovanni Battista Church in Cevio (Switzerland)", Archaeometry, Volume 54, Issue 2, 294-310.

FIEMA, Z.T. / HOLMGREN, R. 2002.

"The Byzantine Monastic/Pilgrimage Center of St. Aaron near Petra". in J. Frösén and Z.T. Fiema (eds.) Petra. A City Forgotten and Rediscovered. Helsinki: Helsinki University Press. 99-110.

FREESTONE I. C. 2015.

"The Recycling and Reuse of Roman Glass: Analytical Approaches", Journal of Glass Studies Volume 57, 29-40.

FREESTONE, I. C. / LESLIEE, K. A. / THIRLWALL, M./ GORIN-ROSEN, 2003.

"Strontium Isotopes in the Investigation of Early Glass Production: Byzantine and Early Islamic Glass from the Near East", Archaeometry, Vol. 45/1, 19-32.

KOZBE, G. / GÖK S., 2018.

"Cizre Kalesi Orta Çağ Barbutin ve Kalıba Bask1 Bezemeli Sırsız Seramikleri”, (Ed. Filiz Yenisehirlioğlu) XI. AIECM3 Uluslararası Orta Çağ ve Modern Akdeniz Dünyası Seramik Kongresi Bildirileri, Cilt 1-2, Vekam Yayınları, Ankara, 309-318.
KURSULA, P. K. 2000.

"Accuracy, precision and detection limits of SEM-WDS, SEM-EDS and PIXE in the multielemental analysis of medieval glass", X Ray Spectrometry, 29/1,111-118.

LI, Q. / LIU, S. /SU, B. / ZHAO, H. / FU, Q. / DONG, J. 2012. "Characterization of some tin-contained ancient glass beads found in China by means of SEM-EDS and raman spectroscopy" Microscopy Research and Technique Volume 76/2, 133-140.

MANTLER, M. / SCHREINER, M. 2000.

"X-ray Fluorescence Spectrometry in Art and Archaeology", X-Ray Spectrometry,29/1, 3-17.

OHNO, Y. 2007.

"Spectral Colour Measurement", in CIE Colorimetry: Understanding the CIE System, J. Schanda, Ed., Ch. 5., Wiley, New York, 101-132.

SILVESTRI, A. 2008.

"The coloured glass of Iulia Felix", Journal of Archaeological Science, Vol. 35, 1489-1501

SILVESTRI, A. / MOLIN, G. / SALVIULO, G. / SCHIEVENIN, R. 2006.

"Sand for Roman glass production: An experimental and philological study on source of supply", Archaeometry, Vol.48/3, 415-432.

SILVESTRI, A. / MOLIN, G. / SALVIULO, G. 2005. "Roman and Medieval Glass from the Italian Area: Bulk Characterization and Relationships with Production Technologies", Archaeometry, Vol. 47/4, 797-816.

SPEAKMAN, R. J. / LITTLE, N. C. /CREEL, D. / MILLER, M.R. / INANEZ, J. G. 2011.

"Sourcing ceramics with portable XRF spectrometers? A comparison with INAA using Mimbres pottery from the American Southwest", Journal of Archaeological Science 30, 3483-3496.

SPENCER, H. M. / MURDOCH, K. R. / BUCKMAN, J. / FORSTER, A. M ./ KENNEDY, C. J. 2018.

"Compositional analysis by $\mathrm{p}-\mathrm{XRF}$ and SEM-EDX of medieval window glass from Elgin Cathedral, Northern Scotland" Archaeometry Volume 60/5,1018-1035.

TITE, M. S. / SHORTLAND, A. J. / MANIATIS, Y. / KAVOUSSANAKI, D. / HARRIS, S.A. 2006.

"The composition of the soda-rich and mixed alkali plant ashes used in the production of glass", Journal of Archaeological Science, Vol. 33, 1284-1292. 